\title{
Cinefan 2006
}

\author{
By Ron Holloway
}

Fall 2006 Issue of KINEMA

\section{CINEFAN NEW DELHI FESTIVAL 2006}

When I asked an informed critic for an opinion as to which was the most important film festival in India today, he named Osian's Cinefan in a close tie with the Trivandrum International Film Festival - with the caveat, of course, that Cinefan in New Delhi primarily presents Asian cinema, while Trivandrum (aka Triruvananthapuram, to use the official name) in Kerala opens its doors wide to international film fare. As for the long-running International Film Festival in India (IFFI), a government-sponsored affair based in Goa for the past couple of years, I was told that it ranked third at best, although a larger attendance was recorded last year. In other words, Goa, a resort city populated mostly by tourists from home and abroad, has had to work hard to attract a movie-mad Indian public from across the country.

Two other festivals were also thrown into the melee: Kolkata (Calcutta) and Mumbai (Bombay), both feeding upon major production centres with long traditions for supporting auteur directors. Some other Indian film festivals were named in passing - the Mumbai International Festival of Documentaries, Shorts, and Animation Films, for instance. And there's also a growing film festival in Pune, where the country's National Film Archive and National Film School are located.

Under the tireless leadership of Osian's Neville Tuli (founder-chairman) and Cinefan's Aruna Vasudev (founder-director), the $8^{\text {th }}$ Osian's Cinefan Festival of Asian Cinema in New Delhi (14-23 July 2006) set new standards of Asian cinema excellence. "For six years I have built Osian's with a relatively clear vision," said Neville Tuli. "Recently Osian's became the proud owners of Minerva cinema in Mumbai, the site of what is about to become the 'Osianama,' a unique integrated arts and film institution." And he added: "Hopefully this time next year Osian's-Cinefan will be simultaneously functioning in Delhi and Mumbai, itself a major integrating step forward." To this end, Indian filmmaker Mani Kaul has joined Osian's as creative director for the new film house at Osianama.

Aruna Vasudev, too, feels that Osian's-Cinefan is growing by leaps and bounds. "In the eight years since the launching of our festival, Osian's-Cinefan has undergone sweeping changes - from 20 films in 1999 as Cinefan, the Cinemaya Festival of Asian Cinema, to 120 films now as Osian's-Cinefan." And she emphasized that "along the way we have added a competition for Indian cinema and, most importantly, IBM2 - the Infrastructure Building for Minds and Markets covering a multitude of events, from the Talent Campus to seminars and Round Tables, debates and panel discussions on a range of subjects, to exhibitions of popular and fine arts, and an auction of Film Memorabilia."

This year's 215-page catalogue, accurate down to the finest detail, offered credits, synopses, bio-filmographies, past awards, comments, and directorial notes on the 120 films from 30 countries in the program. Four international juries were summoned for the Asian Competition, Indian Competition, NETPAC (Network for the Promotion of Asian Cinema), and FIPRESCI (International Critics). Most of the screenings at the triple-screen Siri Fort complex and the adjunct at the Alliance Française were sell-outs. Cinemaya's Latika Padgaonkar organized a two-day international media roundtable titled "Beyond Cinema" with such leading critics of Asian cinema as France's Max Tessier and Britain's Tony Rayns. One of the master classes at the Talent Campus, courtesy of the Berlinale and the Max Mueller Bhavan (Goethe-Institut) in India, featured eminent French screenwriter Jean-Claude Carrière - whose book, In Search of the Mahabharata Notes of Travels in India with Peter Brook, 1982-1985, had been translated into English by Aruna Vasudev. Filmmakers, critics, and guests were quartered comfortably at the Imperial Hotel and the Taj Mahal.

Besides the Asian and Indian Competitions, the festival program embraced a wide range of Asian cinema under some rather teasing title: Asian Frescoes (awarded Asian films of the past couple seasons), Indian Osean (new Indian productions), Arabesque (Arab cinema), Cross-Cultural Encounters (how Western countries treat Asian themes), The Middle Path: A Focus on Buddhism (classic and recent films on Buddhism), In-Tolerance (wars in the Near East and Southeast Asia), Special Screenings (eg the world premiere of 
a directorial debut by renown Indian actor Naseeruddin Shah), Stanley Kwan Retrospective (moderated by British critic Tony Rayns), Ritwik Ghatak Retrospective (to commemorate the Bengal director's 80th birthday), and New Theatres Retrospective (legendary Calcutta production company launched in 1931). To top it all off, Taiwan's Peggy Chiao was honoured with the festival's Lifetime Achievement Award for her contribution to Asian cinema as author, critic, screenwriter, and producer. For many, Peggy Chiao was, and is, the backbone of New Taiwan Cinema.

Osian's-Cinefan 8 opened with the world premiere of Pan Nalin's Valley of Flowers (India-France-JapanGermany), a folkloric tale about bandits and bounty hunters that spans two centuries from the days of the Silk Road to the early 19th century. This "Eastern" is particularly noteworthy for its splendid shots of the Himalayan mountain passes. The festival closed with one of the finest comedies ever to emerge from Iran: Jafar Panahi's Offside.

The setting is a soccer game at overcrowded Azadi Stadium in Tehran - not just any soccer game, for Iran is battling Bahrain in a key match to qualify for the World Cup in Germany. Six dauntless Iranian girls use their wits and disguises to enter the stadium as boys, hoping that their assortment of caps, dress, pennants, and painted faces will squeeze them by the guards at the gate. One even dons a soldier's uniform, an indiscretion that could easily lead to family disgrace and a jail sentence. The girls never get to see the game - instead, they are placed "offside" in a pen under the guard of a friendly soldier who wants to watch the game as badly as they do. The rest is an ongoing dialogue between the girls and the guards about the whys and wherefores for forbidding women to enter a soccer stadium in the first place. Illogical answers to logical questions can bring howls of laughter.

A packed house for the world premiere of Naseeruddin Shah's Yun hot toh kya hota? (What If?) was a foregone conclusion. And, indeed, the popular Indian actor has directed another moving memorial to victims of the 9/11 airlines hijacking. Placing Indian passengers in the foreground of the tragedy - just as Paul Greengrass's United 93 (USA-UK) fictionalized what might have happened on the hijacked 9/11 United Airlines flight that crashed into a field instead of the intended White House - Naseeruddin Shah focuses on the fates of four individuals from different social backgrounds who connect with a flight in Boston while on their way from India to separate destinies in the States. Of the four narratives the one that tugs at the emotions the most is the story of a young girl who, thanks to a long-lost father she has just come to know, joins his amateur folkloric troupe on a tour of American cities. One scene in the film is a standout: when the troupe appears at an American Consulate to obtain their collective visas, they spontaneously burst into an hilarious improvised performance of their song-and-dance routines. Stateside Indian-American audiences will love it!

Jeffrey Jeturian's Kubrador (The Bet Collector, Philippines) was awarded Best Asian Film. For three days we follow Amelita (Gina Pareno), an aging woman bet collector, who makes her living on the streets of Manila by working the numbers racket. Called jueteng, the illegal numbers game dates from as far back as the Spanish colonial period. Since Amelita depends on jueteng for her livelihood, and her customers wouldn't have it any other way, she is not at all taken back by a police arrest. The next day, she's back on her numbers beat again. Gina Pareno's loose, hands-on performance in this docu-drama won her the Best Actress award. And, in a first of its kind, The Bet Collector, already the recipient of the International Critics (FIPRESCI) Award at the Moscow film festival in June, was voted the FIPRESCI Award again at New Delhi. If nothing else, the double-whammy guarantees further festival exposure and possibly an arthouse release.

By coincidence, Kutlug Ataman's Iki genc kiz (Two Girls, Turkey), awarded the Special Jury Prize at New Delhi, had also been awarded amply over the past year at Turkish festivals in Istanbul, Antalya, and Ankara. The story of two rebellious teenagers in Istanbul - one is the daughter of an attractive woman-of-the-world, the other is a waif from the outskirts - they meet at shopping malls and hip corners of the city with no other aim in life than to escape from their drab family milieu. Two Girls is the kind of film that disturbs, for the troubles mutually faced by the girls at home and on the street are all too familiar.

A similar "city film" in the Indian Competition, Subrato Sen's Bibar (Calcutta, Unabashed), merited Best Actor and Best Actress for, respectively, Subrat Dutta and Tannishtha Chatterjee. Based on a novel with the same title, Calcutta, Unabashed exposes the soft underbelly of the fast-moving financial world, where bribes and corruption are the order of the day. Stripped of a traditional family ethic and a coherent moral 
code, a young go-getter in a finance company compromises whatever his values he has left in his carefree life when he meets a high-class call-girl and then takes to drinking to wash away his guilt. The traditional code is also at the core of Ramachandra RN's Suddha (The Cleansing Rites), awarded Best Indian Film. The story of family in a provincial Karnataka village of South India, tensions surface among the relatives when a decision has to be made in regard to the ritual burial on a grand scale of the grandmother of once-powerful landowning gentry. Who should perform the rites? Who is to pay for the funeral? And what to do afterwards with a decaying estate that none of the descendants want to look after? As confirmed by many attending the Osian's-Cinefan festival, these are questions all too familiar in a modern-day India still chained to a feudal past.

The NETPAC Award went to Khongdej Jaturanrassamee's Cherm (Midnight My Love, Thailand) "for its warm and humorous approach to an interpersonal relationship as interpreted by two outstanding acting performances." Programmed in the Asian Frescoes section, Midnight My Love comes across as a tongue-incheek, deadpan, slapstick-style melodrama about a lonely middle-aged taxi driver taken by the charms of a bar-girl who dreams of opening a bridal shop one day. Letters written by the taxi-driver to a DJ on a radio station that plays old-time hits blend with dream sequences on both sides. A low-key film, Midnight My Love deftly teases and tickles the emotions.

Another film in the Asian Frescoes program that impressed was Hur Jin-Ho's Wae chul (April Snow, Korea). Hur Jin-Ho's string of tragic love stories have already rendered him auteur status in South Korean cinema. His Christmas in August (1998), the story of a police woman in love with a photographer afflicted with a terminal illness that he tries to hide, was a hit at the Korean box office and on the international festival circuit. So, too, was his One Fine Spring Day (2001), the bittersweet story about a sound recording engineer hopelessly in love with an anchor-woman at a local TV station. In April Snow a car crash leaves two lovers in a coma, a situation that proves quite embarrassing to both spouses when they are called to the hospital. Gradually, however, the betrayed husband and wife get to know each other, enough to appreciate the twist of fate that has brought them together - only to part when one crash victim recovers and the other does not.

As for the best Asian film on view at Osian's-Cinefan, my vote goes to Nuri Bilge Ceylan's Iklimler (Climates, Turkey). [More on this film in my Cannes report in this issue.]

In the retrospective honouring Ritwik Ghatak (1925-1976) were seven films by this Marxist thinker and revolutionary filmmaker. Ajantrik (Pathetic Fallacy, 1958), Bari theke paliye (The Runaway, 1959), Meghe dhaka tara (The Cloud-Capped Star, 1960), Komal Gandhar (E-Flat, 1961), Subarnarekha (note: the name of a river, 1962), Titas ekti nadir naam (A River Named Titas, 1973), and Jukti takko aar gappo (Arguments and a Story, 1974), an overlooked contemporary of Satyajit Ray, Ritwik Ghatak's central theme was the partition of Bengal. One of the films in the retro brought back memories.

Back in January of 1988, while on a six-week trip through India, I paid a visit to Ritwik Ghatak's modest studio on a backstreet in Calcutta at the invitation of his son. There, on the white-washed wall of the studio, he projected a worn and scratchy print of The Cloud-Capped Star. The story of the sacrifices made by the eldest daughter of a refugee family from East Bengal, as they struggle for survival on the outskirts of an overcrowded city, I have never forgotten that projection until this day. As Satyajit Ray once stated, "Ritwik was one of the few truly original talents in the cinema this country has produced." Hopefully, the Ritwik Ghatak retro will find its way abroad.

\section{References}

\section{AWARDS}

\section{Asian Competition}

\section{Best Film}

Kubrador (The Bet Collector, Philippines), dir Jeffrey Jeturian

\section{Special Jury Prize:}

Iki genc kiz (Two Girls, Turkey) 
dir Kutlug Ataman

\section{Special Mentions:}

Ontarjatra (Homeland, Bangladesh)

dir Tareque and Catherine Masud

Gu lian hua (Love's Lone Flower, Taiwan),

dir Tsao Jui-Yuan

\section{Best Actress:}

Gina Pareno, Kubrador (The Bet Collector, Philippines),

dir Jeffrey Jeturian

\section{Best Actor}

No award given

\section{Indian Competition}

Best Film

Suddha (The Cleansing Rites)

dir Ramachandra PN

\section{Special Jury Prize}

Nayi Neralu (In the Shadow of the Dog)

dir Girish Kasaravalli

\section{Best Actor}

Subrat Dutta, Bibar (Calcutta, Unabashed)

dir Subrato Sen

\section{Best Actress}

Tannishtha Chatterjee, Bibar (Calcutta, Unabashed), dir Subrato Sen

\section{FIPRESCI (International Critics) Award}

Kubrador (The Bet Collector, Philippines)

dir Jeffrey Jeturian

NETPAC Award (Network for the Promotion of Asian Cinema)

Cherm (Midnight My Love, Thailand)

dir Khongdej Jaturanrassamee

Lifetime Achievement Award

Author-critic-producer Peggy Chiao Hsiung-ping (Taiwan)

\section{Author Information}

Ron HOLLOWAY (1933-2009) was an American critic, film historian, filmmaker and correspondent who adopted Europe as his home in the early fifties and spent much of his life in Berlin. He was an expert on the study of German cinema and against all odds produced, with his wife Dorothea, the journal German Film, keeping us up-to-date with the work of directors, producers and writers and the showing of German films around the world.

In 2007, Ron Holloway and his wife were awarded the Berlinale Camera Award. Ron also received the Bundesverdienstkreuz (German Cross of Merit), Polish Rings, Cannes Gold Medaille, the American Cinema Foundation Award, the Diploma for Support of Russian Cinema and an honorary award from the German Film Critics' Association.

Ron was also a valued contributor to Kinema for the past fifteen years. 